\title{
Long-term Financial Analysis of the Slovenian Wood Industry Using DEA
}

\section{Dugoročna financijska analiza slovenske drvne industrije primjenom metode DEA}

\author{
Original scientific paper • Izvorni znanstveni rad \\ Received-prispjelo: 14. 3. 2018. \\ Accepted-prihvaćeno: 10. 12. 2019. \\ UDK: $630 * 79$ \\ doi: $10.5552 /$ drvind.2019.1810
}

\begin{abstract}
Long-term financial analysis is an important tool for assessing the financial position of a company and/or sector. The aim of the research was to analyze selected financial indicators of the Slovenian wood industry in sub-sectors C16 (wood processing - except furniture) and C31 (manufacture of furniture) for the last 10 years (from 2007-2016). The efficiency evaluation was performed by DEA (Data Envelopment Analysis) window analysis. Other comparisons between two sub-sectors were performed by analysis of time series of financial indicators and by t-test. We have analyzed 40 financial indicators, 15 of which in more detail. Some models, analyzed by DEA method, show relative deterioration in efficiency in the years 2007-2010, but in most cases efficiency has increased in recent years. With this, we have proven that the efficiency of both sub-sectors is improving. For all models, the performance of the sub-sector C16 is better than that of C31. It has been proven by t-test that the difference between these two sub-sectors is statistically significant, as differences of more than half of the financial indicators between the two sub-sectors are statistically significant. Therefore, improvements in profitability ratios at the company's level should be done and appropriate measures within the sectoral economic policies should be taken to achieve the conditions needed for greater efficiency and success.
\end{abstract}

Keywords: financial analysis, financial indicators, wood industry, Slovenia, DEA, t-test

SAŽETAK • Dugoročna financijska analiza važan je alat za procjenu financijskog stanja poduzeća i/ili sektora. Cilj istraživanja bio je analizirati odabrane financijske pokazatelje slovenske drvne industrije posljednjih deset godina (2007. - 2016.) u podsektorima C16 (prerada drva-osim namještaja) i C31 (proizvodnja namještaja). Procjena učinkovitosti provedena je primjenom analize omeđivanja podataka (DEA - Data Envelopment Analysis). Ostale usporedbe dvaju podsektora obavljene su analizom vremenskih serija financijskih pokazatelja $i$ t-testom. Analizirano je 40 financijskih pokazatelja, od kojih 15 detaljno. Neki modeli analizirani DEA metodom pokazuju relativno pogoršanje učinkovitosti u razdoblju 2007. - 2010., ali se u većini modela učinkovitost tijekom posljednjih nekoliko godina povećala. Time je dokazano da se učinkovitost obaju podsektora poboljšava. Za sve je modele učinak podsektora C16 bolji od učinka podsektora C31. Primjenom t-testa dokazana je statistički značajna razlika između dva promatrana podsektora jer su razlike statistički značajne za više od polovice financijskih pokazatelja koji se odnose na ta dva podsektora. Stoga je potrebno poboljšati omjer profitabilnosti na razini poduzeća i uvesti odgovarajuće mjere u sklopu sektorskih ekonomskih politika kako bi se postigli uvjeti za veću učinkovitost i uspjeh.

Ključne riječi: financijska analiza, financijski pokazatelji, drvna industrija, Slovenija, DEA, t-test

\footnotetext{
${ }^{1}$ Author is assistant professor at University of Ljubljana, Biotechnical Faculty, Department of Wood Science and Technology, Ljubljana, Slovenia. ${ }^{2}$ Author is assistant professor at University of Ljubljana, Biotechnical Faculty, Department of Forestry and Renewable Forest Resources, Ljubljana, Slovenia.

${ }^{1}$ Autor je docent Sveučilišta u Ljubljani, Biotehnički fakultet, Zavod za znanost o drvu i tehnologiju, Ljubljana, Slovenija. ${ }^{2}$ Autorica je docentica Sveučilišta u Ljubljani, Biotehnički fakultet, Zavod za šumarstvo i obnovljive šumske resurse, Ljubljana, Slovenija.
} 


\section{INTRODUCTION}

\section{UVOD}

The financial and operating position of a sector, which is understood as "group of companies that produce and sell similar or identical products or services" (Samuelson and Nordhaus, 2002), depends on various factors of business environment, which is constantly changing. This causes a number of challenges for companies, especially in terms of their performance, and impacts both the conditions and development of the sector as a whole (Kropivšek et al., 2017). In addition, the situation with regard to purchasing and sales markets, and functioning of the sector and/or companies operating within it, is strongly influenced by the general situation in the economic environment of a country, and by the role of particular sector in strategic national economic policy. A sector that plays a strategically important role in a national economy is more likely to be the focus of a number of economic measures, such as: 1) public tenders to subsidize investments in research and development, and 2) carrying out promotional activities in order to achieve greater visibility of the sector, thus raising its position within society. For companies operating within a focal sector, this last point is reflected in the form of easier entry into the market, better positioning due to the good reputation of the sector, and a greater ability to attract and retain the most capable professional staff, something which is the heart of a firm's development. According to some estimates, the woodprocessing industry in Slovenia has experienced relatively stable growth in the last few years (Likar and Valentinčič, 2017). After the unfavorable position of the wood-industry sector in Slovenia in the national economic policies adopted before 2010, significant improvements have occurred in recent years (Kropivšek et al., 2017). There is evidence of the growing consumption and processing of wood in Slovenia, and it is thus vital for the sector to take advantage of the currently favorable conditions.

The success of business operations can be quantitatively measured in a variety of ways (Tekavčič, 2002; Rebernik, 2008). In most cases, it is measured by the amount of profit, growth of assets and ability to assure solvency. The first two criteria are particularly important for long-term success, and the last one for short-term success. For a wider picture of the long- and short-term performance and development of both corporate and industry development orientations, it is necessary to monitor many economic and financial indicators of companies and the economy as a whole. One of the most important tools for assessing the financial position and success of a company and/or sector is financial analysis (Helfert, 2001; Vance, 2003). This is a set of tools and techniques, including fiscal indicators and forecasting, that can be used to measure the current fiscal conditions and performance of a business, and predict their trends (Friedlob and Schleifer, 2003; Palepu et al., 2004). Gitman (2004) pointed out that the only data sources available for financial analysis are firm's financial statements, in which a large amount of data is reduced to a few key parameters. Financial analysis also ensures comparability between companies and/or sectors (Slapničar, 2004), and the main users of such analysis are lenders/creditors, owners/investors and managers.

By analyzing different financial indicators, the performance of the whole sector can be estimated, thus obtaining the key information needed for the creation and modification of sectoral strategies. Financial analysis can reveal certain disadvantages (weaknesses) and risks, and enables a deeper understanding of the entire sector. As such, the results can greatly affect the future development and performance of the sector (Kropivšek and Jošt, 2013).

In general, there are two different methods of financial analysis: (1) horizontal and vertical analysis, and (2) financial ratio analysis (Peterson and Fabozzi, 1999). The method of financial ratio analysis is the most common for evaluating the conditions of a specific company and a sector or industry as a whole, where the resulting ratio is an expression of a mathematical relationship between two quantities (Peterson et al., 2010). However, a single value of a financial ratio is not meaningful by itself, and more important is the time-series analysis of ratios, which involves examining the pattern of ratios over time.

The aim of the current research is to analyze selected financial indicators of the Slovenian wood industry sector for the last 10 years (from 2007-2016). We have assumed (Hypothesis 1) that the situation in the wood industry has been improved in recent years, based on the improving economic stability in general of the Slovenian economy (UMAR, 2017). We have also assumed (Hypothesis 2) that there are some differences between two wood-industry sub-sectors C16 (wood processing - except furniture) and C31 (manufacture of furniture) (Braunsberger et al., 2010). We will analyze financial data and selected financial indicators in time series in the period from 2007 to 2016, and the comparison between the two sub-sectors ( $\mathrm{C} 16$ and $\mathrm{C} 31)$ will be performed using t-test. The efficiency evaluation of the two wood-industry sub-sectors will be carried out using data envelopment analysis (DEA), which is a management tool used to evaluate the relative efficiency of a number of decision units regarding a set of inputs and a set of outputs, based on linear programming.

Although the wood-industry sector in Slovenia has already been analyzed from a financial point of view (Kropivšek et al., 2017; Kropivšek and Jošt, 2013; Kropivšek et al., 2011; Tratnik et al., 2001), the DEA method has not yet been applied, although this approach is widely used around the world for evaluating the efficiency of sectors in addition to the use of financial indicators (Halkos and Tzeremes, 2012a; Halkos and Tzeremes, 2012b; Hoang Bui et al., 2016; $\mathrm{Li}$ and $\mathrm{Wu}, 2016$; Fenyves et al., 2015).

\section{MATERIALS AND METHODS} 2. MATERIJALI I METODE

As mentioned above, in calculating the indicators, the data for all registered (and functioning) com- 
panies and sole proprietors operating in sub-sectors C16 (wood processing-except furniture) and C31 (manufacture of furniture) were considered according to the sub-sector level data in the classification of economic activities NACE (Nomenclature of Economic Activities) rev.2 classification (NACE, 2018). The research was based on searching and preparing data from official statistical databases (Ajpes JOLP, 2017; Analitika GZS, 2018), collected and calculated in aggregate form. The indicators were calculated for the period from 2007 to 2016 (10 years).

The sample size differs slightly in different years due to the various changes in the number of companies in sectors, although the changes were small: in subsector C16 cca. 1.470 companies and in C31 around 1,050 companies on average, in total more than 2,500 companies. In Slovenia, the majority (more than twothirds) of companies in each sub-sector are sole proprietors, and more than $98 \%$ of the companies are micro and small size companies (according to: ZGD-1-UPB3, 2009): in the sub-sector C31 there is one large company, while in $\mathrm{C} 16$ there are three of them (Bisnode, 2018). Before the economic downturn in the year $2008 / 09$, the number of employees was about the same for both sub-sectors, and this number was much higher than in recent years, when the situation changed dramatically. Especially in the sub-sector C31, the number of employees fell by half from 2008 to 2014, and has stayed the same since then, while in sub-sector C16, the decrease was not so dramatic, down by only around $20 \%$, and the number of people employed in this area has even increased slightly since 2015. In total, the number of employees in the wood industry sector fell from more than 20,000 in 2007 to less than 11,500 in 2014, and increased slightly to 12,000 in 2016.

The key issue of successful financial analysis is in the right selection of key performance financial indi- cators. The indicators must be adapted to the intended use, and the number of indicators has to be small (Slapničar, 2004). In order to facilitate a more focused and purposeful selection of indicators, some authors (Pratt, 1990; Rees, 1995; Higgins, 1995; Elliot and Elliot, 1996; Hornby et al., 1997; Mramor, 2002; Tekavčič, 2002; Fabozzi and Peterson, 2003; Slapničar, 2004; Brigham and Huston, 2009; Peršak, 2011; Ajpes $\mathrm{FI}=\mathrm{PO}, 2018$ ) classify indicators into different groups, taking into account the content connectivity of indicators. For the purpose of this research, financial indicators were divided into five categories of ratios: (1) liquidity ratios (which provide information on a firm's ability to meet its short-term obligations), (2) profitability ratios (providing information on how well the company is managing its expenses), (3) activity ratios (with information on a firm's ability to manage its resources efficiently), (4) leverage ratios (including information on the degree of a firm's fixed financing obligations and its ability to satisfy these obligations), and (5) efficiency ratios (indicating a firm's operating efficiency and explaining its business results in relation to various investments that have been made in the business process). Forty financial indicators were analyzed in this research, and the majority of them have been examined in similar studies (Pirc Barčić et al., 2017; Delen et al., 2013; Sayari and Simga Mugan, 2016; Gombola and Ketz, 1983). There were different numbers of indicators in each group, as shown in parentheses: leverage ratios (13), liquidity ratios (3), profitability ratios (7), efficiency ratios (12) and activity ratios (5). However, for further and detailed analysis only 15 indicators were selected (Table 1).

According to Berger and Humphrey (1997), many different approaches can be used for measuring the efficiency of business units. The most notable nonparametric approach is data envelopment analysis

Table 1 A list of analyzed financial indicators

Tablica 1. Popis analiziranih financijskih pokazatelja

\begin{tabular}{|l|l|l|}
\hline \multicolumn{1}{|c|}{ Group / Skupina } & \multicolumn{1}{|c|}{ Financial indicator / Financijski pokazatelj } & \\
\hline Leverage ratio / omjer financijske poluge & Debt to equity ratio / omjer duga i kapitala & D/E \\
\cline { 2 - 3 } & $\begin{array}{l}\text { Total debt (short- and long-term financial debt) to total assets ratio / } \\
\text { omjer ukupnog duga (kratkoročni } \text { i dugoročni financijski dug) } \\
\text { prema ukupnoj aktivi }\end{array}$ & TDA \\
\cline { 2 - 3 } & $\begin{array}{l}\text { Total liabilities to total sources of funds ratio / omjer ukupnih } \\
\text { obveza prema svim izvorima sredstava }\end{array}$ & TLTSF \\
\hline \multirow{5}{*}{ Liquidity ratio / omjer likvidnosti } & Current ratio / trenutačni omjer & CR \\
\cline { 2 - 3 } & Quick ratio / brzi omjer & QR \\
\cline { 2 - 3 } & Cash ratio / novčani omjer & CashR \\
\hline Profitability ratio / omjer profitabilnosti & Return on equity / povrat na kapital & ROE \\
\cline { 2 - 3 } & Return on assets / povrat sredstava & ROA \\
\cline { 2 - 3 } & Return on sales / povrat od prodaje & ROS \\
\hline \multirow{5}{*}{ Activity ratio / omjer aktivnosti } & $\begin{array}{l}\text { Gross value added per employee ratio / omjer bruto dodane } \\
\text { vrijednosti po zaposleniku }\end{array}$ & GVA \\
\cline { 2 - 3 } & Asset turnover ratio / omjer prometa imovine & ATR \\
\cline { 2 - 3 } & Current asset turnover ratio / omjer obrtanja aktive & CAT \\
\hline \multirow{2}{*}{ Efficiency ratio / omjer učinkovitosti } & $\begin{array}{l}\text { Earnings before interest, taxes, depreciation, and amortization / } \\
\text { dobit prije kamata, poreza, deprecijacije } i \text { amortizacije }\end{array}$ & EBITDA \\
\cline { 2 - 3 } & Total efficiency ratio / omjer ukupne učinkovitosti & E \\
\cline { 2 - 3 } & Asset utilization ratio / omjer iskorištenja imovine & AU \\
\hline
\end{tabular}


(DEA), which measures the relative efficiency of production units (from small productive units to entire countries), and the use of this approach is increasing rapidly in both the literature and practice (Hollingsworth and Smith, 2003).

The current study applies DEA window analysis. This is based on the principle of the moving averages (Cooper et al., 2007), and can detect the performance trend of decision-making units (DMUs) over time. In DEA window analysis, each sub-sector in a different period is treated as if it was a different unit, which increases the number of DMUs. This can be convenient when the number of such units is small compared to the number of inputs and outputs. The DEA window analysis is based on windows, which present a fixed number of successive time periods included in the analysis. Since it is assumed that there are no technical changes within each window, narrow windows are recommended. In order to have a narrow window and a sufficiently large sample, five-year windows have been chosen (Asmild et al., 2004). In the first window, data from the year 2007 to 2011 were included. The second window included data from the year 2008 to 2012, while in the last, sixth window, data from the year 2012 to 2016 were included (Table 2).

Table 2 Five-year windows for DEA window analysis Tablica 2. Petogodišnji prozori za DEA analizu

\begin{tabular}{|c|c|}
\hline Window / Prozor & Years / Godine \\
\hline Win 1 & $2007-2011$ \\
\hline Win 2 & $2008-2012$ \\
\hline Win 3 & $2009-2013$ \\
\hline Win 4 & $2010-2014$ \\
\hline Win 5 & $2011-2015$ \\
\hline Win 6 & $2012-2016$ \\
\hline
\end{tabular}

In the analysis, DEA-Solver-LV (8.0), model WIN-I-C, denoting the input-oriented model with constant return to scale, was used (Asmild et al., 2004).
We can consider $N$ decision units (DMUs), $n=1, \ldots, N$ observed for $T$ periods, $t=1, \ldots, T$ that use $r$ inputs to produce $s$ outputs. The sample has $N \times T$ observations and an observation $n$ in period $t$, namely $D M U_{t}^{n}$ , has an $r$-dimensional input vector $x_{t}^{n}=\left(x_{1 t}^{n}, x_{2 t}^{n}, \ldots, x_{r t}^{n}\right)^{\prime}$ and a s-dimensional output vector $y_{\mathrm{t}}^{n}=\left(y_{1 \mathrm{t}}^{n}, y_{2 \mathrm{t}}^{n}, \ldots, y_{\mathrm{st}}^{n}\right)$. The window $k_{w}$ with $k \times w$ observations starts at time $k$, $1 \leq w \leq T$, and has the width $w, 1 \leq w \leq T-k$. Its input matrix is given as follows:

$$
X_{k_{w}}=\left[\begin{array}{cccc}
x_{k}^{1} & x_{k}^{2} & \cdots & x_{k}^{N} \\
x_{k+1}^{1} & x_{k+1}^{2} & \cdots & x_{k+1}^{N} \\
\vdots & \vdots & \ddots & \vdots \\
x_{k+w}^{1} & x_{k+w}^{2} & \cdots & x_{k+w}^{N}
\end{array}\right]
$$

and its output matrix as follows:

$$
Y_{k_{w}}=\left[\begin{array}{cccc}
y_{k}^{1} & y_{k}^{2} & \cdots & y_{k}^{N} \\
y_{k+1}^{1} & y_{k+1}^{2} & \cdots & y_{k+1}^{N} \\
\vdots & \vdots & \ddots & \vdots \\
y_{k+w}^{1} & y_{k+w}^{2} & \cdots & y_{k+w}^{N}
\end{array}\right]
$$

The input-oriented DEA window problem, under the constant return to scale (CRS) assumption for $D M U_{t}^{\prime}$ is then presented by linear program. For further details about DEA models see Cooper et al. (2007).

In our study, five DEA window models were considered. In Model 1, the absolute values of financial data were used, while for the four other models the values of ratios were used (Table 3). The first model was intended to measure the technical efficiency of subsectors. The technical efficiency is the most common efficiency concept for the conversion of physical inputs (I) into outputs $(\mathrm{O})$. The selected inputs and outputs are presented in Table 3.

For models 2-5, the efficiency of sub-sectors was measured by financial ratios. Financial ratios have been used in DEA models in many studies (Hoang Bui et al., 2016; Li and $\mathrm{Wu}, 2016$; Fenyves et al., 2015; Halkos and Tzeremes, 2012a; Halkos and Tzeremes,

Table 3 Inputs and outputs of models 1-5 of DEA window analysis

\begin{tabular}{|c|c|c|c|c|}
\hline $\begin{array}{l}\text { Model } \\
\text { Model }\end{array}$ & \multicolumn{2}{|c|}{ Inputs / Ulazi } & \multicolumn{2}{|c|}{ Outputs / Izlazi } \\
\hline \multirow{3}{*}{ Model 1} & \multicolumn{2}{|c|}{ Assets (A) / imovina (A) } & \multicolumn{2}{|c|}{ Net Sales Revenues (NS) / neto prihodi od prodaje (NS) } \\
\hline & \multicolumn{2}{|c|}{ Capital (C) / kapital (C) } & \multicolumn{2}{|c|}{ Gross Profit (EBIT) / bruto dobit (EBIT) } \\
\hline & \multicolumn{2}{|c|}{ Number of Employees (NE) / broj zaposlenih (NE) } & \multicolumn{2}{|c|}{ Gross Value Added (VA) / bruto dodana vrijednost (VA) } \\
\hline \multirow{3}{*}{ Model 2} & \multirow{3}{*}{$\begin{array}{c}\text { Leverage ratio } \\
\text { omjer financijske } \\
\text { poluge }\end{array}$} & $\mathrm{D} / \mathrm{E}$ & \multirow{3}{*}{$\begin{array}{l}\text { Liquidity ratio } \\
\text { omjer likvidnosti }\end{array}$} & $\mathrm{CR}$ \\
\hline & & TDA & & QR \\
\hline & & TLTSF & & CashR \\
\hline \multirow{3}{*}{ Model 3} & \multirow{3}{*}{$\begin{array}{c}\text { Leverage ratio } \\
\text { omjer financijske } \\
\text { poluge }\end{array}$} & $\mathrm{D} / \mathrm{E}$ & \multirow{3}{*}{$\begin{array}{l}\text { Profitability ratio } \\
\text { omjer profitabilnosti }\end{array}$} & ROA \\
\hline & & TDA & & ROE \\
\hline & & TLTSF & & ROS \\
\hline \multirow{3}{*}{ Model 4} & \multirow{3}{*}{$\begin{array}{c}\text { Leverage ratio } \\
\text { omjer financijske } \\
\text { poluge }\end{array}$} & $\mathrm{D} / \mathrm{E}$ & \multirow{3}{*}{$\begin{array}{l}\text { Activity ratio } \\
\text { omjer aktivnosti }\end{array}$} & GVA \\
\hline & & TDA & & ATR \\
\hline & & TLTSF & & CAT \\
\hline \multirow{3}{*}{ Model 5} & \multirow{3}{*}{$\begin{array}{c}\text { Leverage ratio } \\
\text { omjer financijske } \\
\text { poluge }\end{array}$} & $\mathrm{D} / \mathrm{E}$ & \multirow{3}{*}{$\begin{array}{l}\text { Efficiency ratio } \\
\text { omjer učinkovitosti }\end{array}$} & EBITDA \\
\hline & & TDA & & $\mathrm{E}$ \\
\hline & & TLTSF & & $\mathrm{AU}$ \\
\hline
\end{tabular}

Tablica 3. Ulazi i izlazi modela 1. - 5. DEA analize prozora 
2012b, Nikoomaram et al., 2010; Oberholzer and van derWesthuizen, 2004). Based on these previous studies, three indicators were selected from each of five groups of indicators. Leverage ratios were set up as inputs of all models 2-5, liquidity ratios for outputs of model 2, profitability ratios for outputs of model 3 , activity ratios for outputs of model 4 and efficiency ratios as outputs of model 5. The selected inputs and outputs are presented in Table 3.

The data in DEA models should be non-negative. When this is not the case, the data should be appropriately translated (Pastor and Ruiz, 2007). The translations were conducted by gross profit (EBIT) and by ROA and ROE indicators. For the input indicators, debt to equity ratio (D/E), TDA and TLTSF, smaller values are more desirable. In order to include these into the models, they were multiplied by (-1) and an appropriate translation process was conducted to gain positive values (Seiford and Zhu, 2002).

For all indicators included in inputs and outputs from models 1-5 (Table 3), the time series in the period from 2007 to 2016 were analyzed and two sub-sectors were compared using t-test.

\section{RESULTS AND DISCUSSION \\ 3. REZULTATI I RASPRAVA}

\subsection{Analysis of time series of indicators}

3.1. Analiza vremenskih serija pokazatelja

Most of the analyzed indicators show an improvement in both sub-sectors within the 10-year period examined in this work. In the years following the economic crisis (2008-2010), their values deteriorated markedly. The greatest deterioration was observed in all profitability ratios, while both the companies and sector as a whole showed significant losses during this period. The efficiency and activity ratios also decreased during this period. Some of them fell by more than $20 \%$, indicating a serious problem in ensuring effective and efficient operations. Interestingly, the liquidity ratios did not significantly deteriorate during this period, which is probably due to the relatively low indebtedness of companies in the sector. Comparing two subsectors, the economic crisis and other changes in economic and political environment influenced the C31 sub-sector more than $\mathrm{C} 16$. On the other hand, the values of most indicators for both sub-sectors have improved since 2013. This is especially true for the profitability ratios as well as for some other indicators, where the values in 2016 reached or even exceeded those seen before the crisis in 2007 , showing clearly an improvement in the companies performance.

\subsection{Comparison of sub-sectors}

3.2. Usporedba podsektora

The inputs and outputs between the two sub-sectors were compared using $t$-test. For Model 1, the results show that there are statistically significant differences between the two sub-sectors for Assets $(t=10.172$, $p<0.001)$, Capital $(t=7.488, p<0.001)$, Net Sales Revenue $(t=7.869, p<0.001)$, Gross Profit $(t=3.726$, $p=0.002)$ and Gross Value Added ( $t=5.634, p<0.001)$. For Models 2, 3, 4 and 5 there are statistically significant differences between the two sub-sectors for ROA $(t=2.646, p=0.016)$, ROE $(t=2.653, p=0.016)$, ROS $(t=2.714, p=0.014)$, GVA $(t=2.970, p=0.008)$, CAT $(t=3.527, p=0.002)$, EBITDA $(t=6.258, p<0.001)$ and $\mathrm{E}(t=2.856, p=0.010)$.

There are statistically significant differences for more than half of the financial indicators between the two sub-sectors, confirming Hypothesis 2, that there are differences between the two wood-industry subsectors (C16 and $\mathrm{C} 31)$.

\subsection{DEA analysis}

3.3. DEA analiza

Descriptive statistics of inputs and outputs of Models 1-5 are presented in Tables 4 and 5.

The results of DEA window analysis for Models 1 are presented in Table 6 and Figure 1, for other models (Model 2-5) only the window averages for both sub-sectors C16 and C31 are presented in Figures 2-5.

The efficiency of converting assets, capital and employees into revenue, profit and value added (Table 6) for the whole period is higher in sub-sector $\mathrm{C} 16$ than in sub-sector C31. The results suggest that efficiency has been increasing in sub-sector C16 in recent years, and reached the highest value in the last period. On the other hand, in sub-sector C31 efficiency was increasing in the early years of the study period, and then fell in the last few years, indicating a decline in the efficiency of this sector (Figure 1).

If three indicators from the leverage group, which show the methods of financing the related business, are taken as inputs and the remaining groups of indicators (liquidity, profitability, activity and efficiency ratios) as outputs, similar conclusions are obtained (Figures 2-5). For all models, the performance in sub-sector C16 is better than that in $\mathrm{C} 31$, which seems to have been more strongly affected by the economic downturn and other

Table 4 Descriptive statistics of variables in Model 1 (all values in $€$; except NE whose values are expressed in numbers) Tablica 4. Deskriptivna statistika varijabli u modelu 1. (sve su vrijednosti u EUR, osim NE, koja je iskazana brojem)

\begin{tabular}{|l|r|r|r|r|}
\hline \multicolumn{1}{|c|}{$\begin{array}{c}\text { Financial indicator } \\
\text { Financijski pokazatelj }\end{array}$} & \multicolumn{1}{c|}{ Mean } & \multicolumn{1}{c|}{ Min } & \multicolumn{1}{c|}{ Max } & \multicolumn{1}{c|}{ Std. Dev. } \\
\hline Assets (A) / imovina (A) & $605,630,777.34$ & $349,402,733.00$ & $824,705,096.00$ & $180,456,671.33$ \\
\hline Capital (C) / kapital (C) & $243,555,942.40$ & $142,445,079.00$ & $416,013,111.00$ & $82,537,071.67$ \\
\hline Number of Employees (NE) / broj zaposlenih (NE) & $7,299.08$ & $4,334.57$ & $10,703.20$ & $1,983.45$ \\
\hline Net Sales Revenues (NS) / neto prihodi od prodaje (NS) & $593,058,209.41$ & $315,411,300.00$ & $949,992,339.00$ & $200,230,054.89$ \\
\hline Gross Profit (EBIT) / bruto dobit (EBIT) & $14,393,133.18$ & $-10,199,137.00$ & $57,836,755.00$ & $19,505,698.61$ \\
\hline Gross Value Added (VA) / bruto dodana vrijednost (VA) & $179,650,068.50$ & $105,524,633.00$ & $269,211,748.00$ & $51,194,051.42$ \\
\hline
\end{tabular}


Table 5 Descriptive statistics of variables in Models 2, 3, 4, and 5

Tablica 5. Deskriptivna statistika varijabli u modelima 2., 3., 4. i 5.

\begin{tabular}{|c|c|c|c|c|c|}
\hline $\begin{array}{l}\text { Group } \\
\text { Skupina }\end{array}$ & $\begin{array}{c}\text { Financial indicator } \\
\text { Financijski pokazatelj }\end{array}$ & Mean & Min & Max & Std. Dev. \\
\hline \multirow{3}{*}{$\begin{array}{c}\text { Leverage ratio } \\
\text { omjer financijske } \\
\text { poluge }\end{array}$} & $\mathrm{D} / \mathrm{E}$ & 1.424 & 0.910 & 1.750 & 0.219 \\
\hline & TDA & 0.299 & 0.206 & 0.348 & 0.041 \\
\hline & TLTSF & 0.565 & 0.454 & 0.619 & 0.041 \\
\hline \multirow{3}{*}{$\begin{array}{l}\text { Liquidity ratio } \\
\text { omjer likvidnosti }\end{array}$} & $\mathrm{CR}$ & 1.098 & 0.980 & 1.390 & 0.102 \\
\hline & QR & 0.713 & 0.610 & 0.960 & 0.092 \\
\hline & CashR & 0.175 & 0.120 & 0.360 & 0.062 \\
\hline \multirow{3}{*}{$\begin{array}{l}\text { Profitability ratio } \\
\text { omjer profitabil- } \\
\text { nosti }\end{array}$} & ROA & 0.008 & -0.045 & 0.069 & 0.033 \\
\hline & ROE & 0.015 & -0.129 & 0.182 & 0.082 \\
\hline & ROS & 0.005 & -0.051 & 0.061 & 0.033 \\
\hline \multirow{3}{*}{$\begin{array}{c}\text { Activity ratio } \\
\text { omjer aktivnosti }\end{array}$} & GVA & $24,963.567 €$ & $17,920.860 €$ & $35,594.670 €$ & $5,047.188 €$ \\
\hline & ATR & 0.972 & 0.830 & 1.150 & 0.098 \\
\hline & CAT & 2.321 & 1.940 & 2.610 & 0.192 \\
\hline \multirow{3}{*}{$\begin{array}{c}\text { Efficiency ratio } \\
\text { omjer učinkovitosti }\end{array}$} & EBITDA & $45,750,741.100 €$ & $14,108,627.000 €$ & $97,855,636.000 €$ & $25,624,651.697 €$ \\
\hline & $\mathrm{E}$ & 1.009 & 0.950 & 1.070 & 0.033 \\
\hline & $\mathrm{AU}$ & 1.007 & 0.870 & 1.180 & 0.099 \\
\hline
\end{tabular}

Table 6 A five-year window analysis of Model 1

Tablica 6. Analiza petogodišnjih prozora modela 1.

\begin{tabular}{|l|c|c|c|c|c|c|c|c|c|c|c|}
\hline Model 1 & $\mathbf{2 0 0 7}$ & $\mathbf{2 0 0 8}$ & $\mathbf{2 0 0 9}$ & $\mathbf{2 0 1 0}$ & $\mathbf{2 0 1 1}$ & $\mathbf{2 0 1 2}$ & $\mathbf{2 0 1 3}$ & $\mathbf{2 0 1 4}$ & $\mathbf{2 0 1 5}$ & $\mathbf{2 0 1 6}$ & Average \\
\hline C16, Win 1 & 1.0000 & 1.0000 & 0.8903 & 0.9343 & 1.0000 & & & & & & 0.9649 \\
\hline C16, Win 2 & & 1.0000 & 0.8728 & 0.9230 & 0.9864 & 1.0000 & & & & & 0.9564 \\
\hline C16, Win 3 & & & 0.8873 & 0.9419 & 0.9929 & 1.0000 & 1.0000 & & & & 0.9644 \\
\hline C16, Win 4 & & & & 0.9419 & 0.9929 & 1.0000 & 0.9991 & 1.0000 & & & 0.9868 \\
\hline C16, Win 5 & & & & & 0.9941 & 1.0000 & 0.9991 & 1.0000 & 1.0000 & & 0.9987 \\
\hline C16, Win 6 & & & & & & 1.0000 & 0.9991 & 1.0000 & 1.0000 & 1.0000 & 0.9998 \\
\hline C16, Average & 1.0000 & 1.0000 & 0.8835 & 0.9353 & 0.9933 & 1.0000 & 0.9993 & 1.0000 & 1.0000 & 1.0000 & 0.9785 \\
\hline C31, Win 1 & 1.0000 & 0.9877 & 0.8270 & 0.8910 & 0.8787 & & & & & & 0.9169 \\
\hline C31, Win 2 & & 1.0000 & 0.8517 & 0.9893 & 0.9352 & 0.9216 & & & & & 0.9396 \\
\hline C31, Win 3 & & & 0.9508 & 1.0000 & 0.9708 & 0.9472 & 1.0000 & & & & 0.9737 \\
\hline C31, Win 4 & & & & 1.0000 & 0.9703 & 0.9265 & 0.9779 & 0.9889 & & & 0.9727 \\
\hline C31, Win 5 & & & & & 1.0000 & 0.9371 & 0.9334 & 0.9716 & 1.0000 & & 0.9684 \\
\hline C31, Win 6 & & & & & & 0.9144 & 0.8738 & 0.9450 & 0.9668 & 1.0000 & 0.9400 \\
\hline C31, Average & 1.0000 & 0.9939 & 0.8765 & 0.9701 & 0.9510 & 0.9294 & 0.9463 & 0.9685 & 0.9834 & 1.0000 & 0.9519 \\
\hline
\end{tabular}

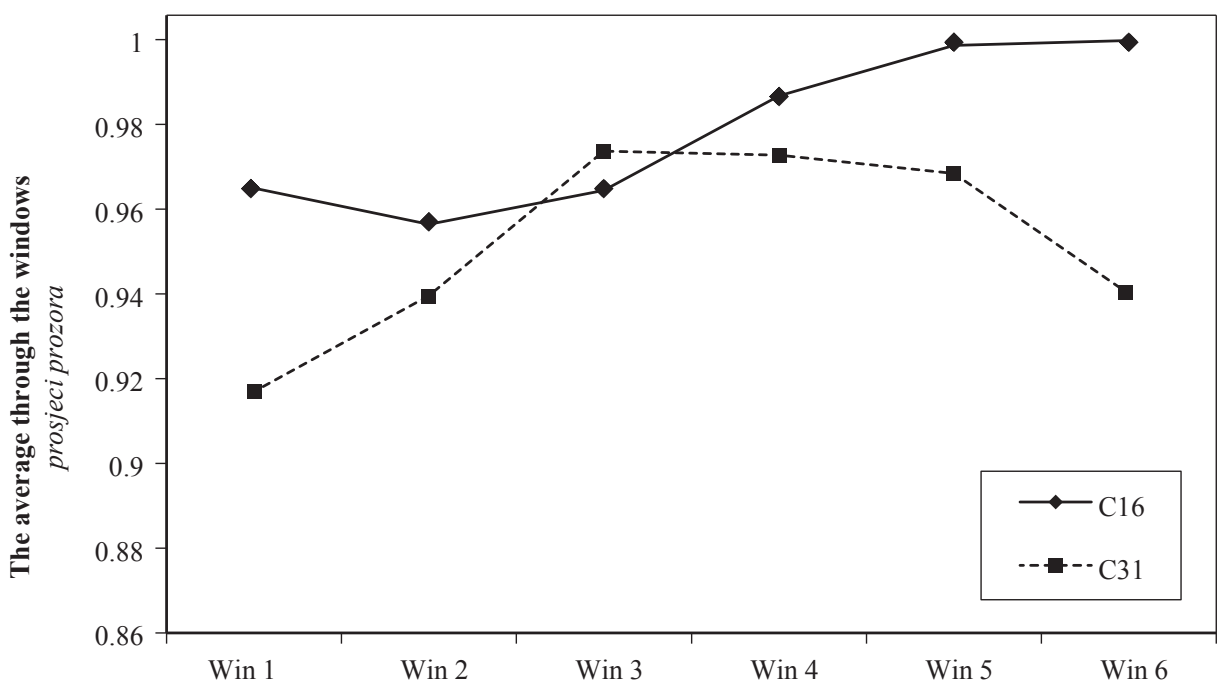

Windows (five-year time period) / prozori (petogodišnje razdoblje)

Figure 1 Window averages of sub-sectors C16 and C31 for Model 1

Slika 1. Prosjeci prozora za podsektore C16 i C31 za model 1. 


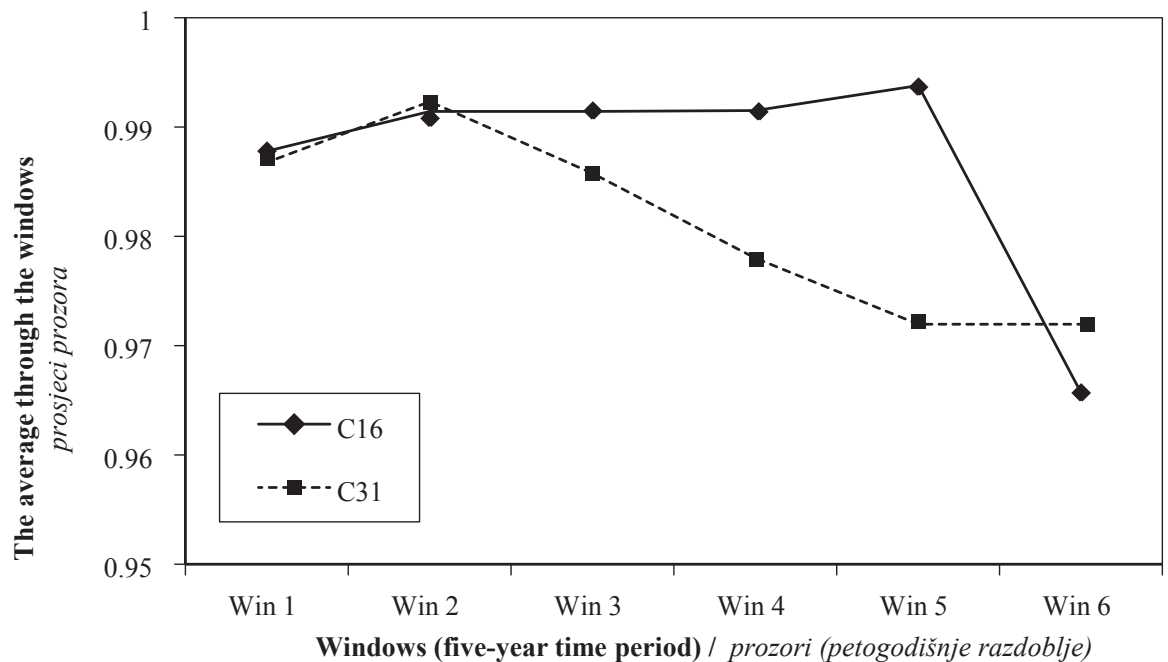

Figure 2 Window averages of sub-sectors $\mathrm{C} 16$ and $\mathrm{C} 31$ for Model 2

Slika 2. Prosjeci prozora za podsektore C16 i C31 za model 2.

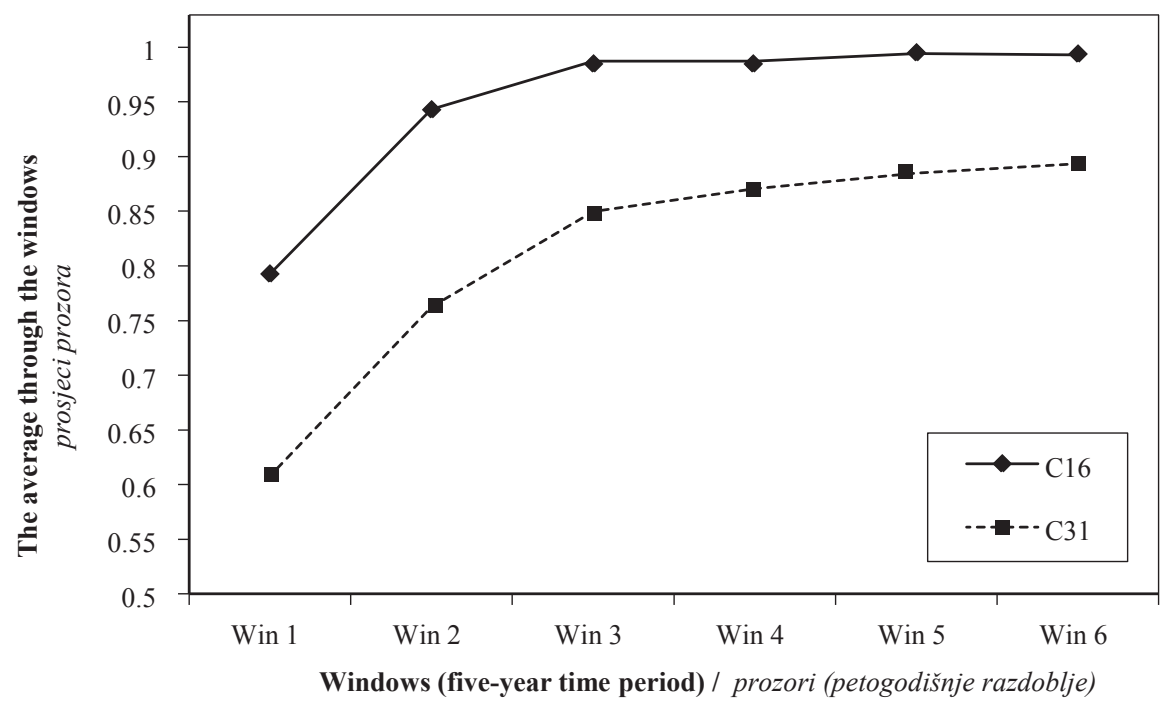

Figure 3 Window averages of sub-sectors $\mathrm{C} 16$ and C31 for Model 3

Slika 3. Prosjeci prozora za podsektore C16 i C31 za model 3.

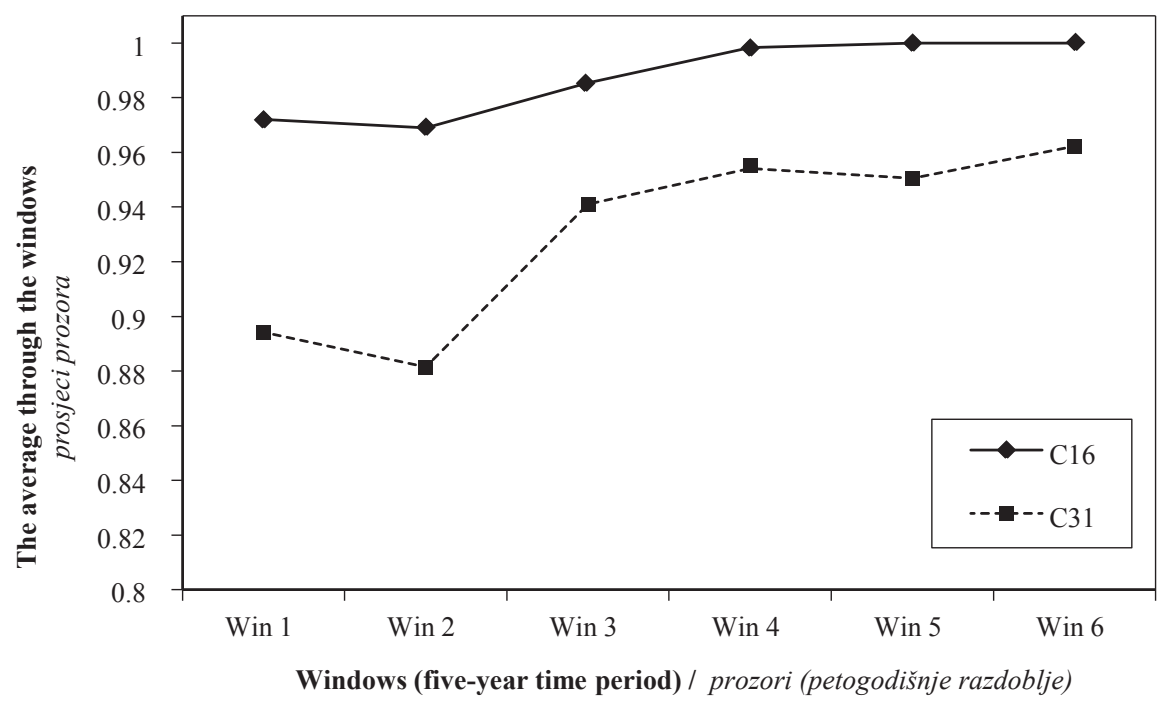

Figure 4 Window averages of sub-sectors C16 and C31 for Model 4

Slika 4. Prosjeci prozora za podsektore C16 i C31 za model 4. 


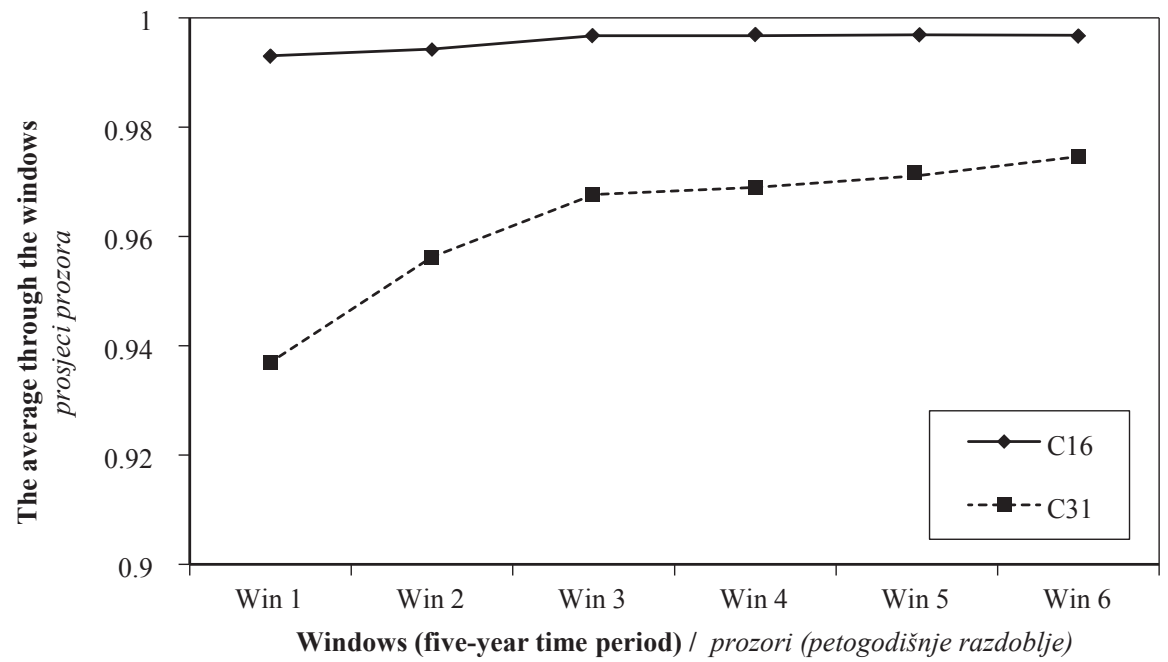

Figure 5 Window averages of sub-sectors C16 and C31 for Model 5

Slika 5. Prosjeci prozora za podsektore C16 i C31 za model 5.

(economic) impacts. In absolute terms, sub-sector C31 shows the worst performance in profitability ratios (Figure 3) (the window averages range from 0.61 to 0.89 ) and the best performance in efficiency ratios (Figure 5) (the window averages range from 0.94 to 0.97). However, a remarkable improvement in efficiency for both sub-sectors has been seen in recent years. A similar improvement can be seen in the activity ratios (Figure 4), while for the liquidity ratios the average window values have been falling in recent years (for both sub-sectors), although their absolute values are still very high (more than 0.96) (Figure 2). Based on the DEA analysis, it has been proved that sub-sector $\mathrm{C} 16$ is more efficient than $\mathrm{C} 31$, and the analysis of the indicators time series and DEA show that hypothesis 1 is confirmed.

\section{CONCLUSIONS}

\section{ZAKLJUČAK}

One of the most important tools for assessing the financial position and success of a company and/or sector is financial analysis. Economic stability and growth in general have recently improved in Slovenia (UMAR, 2017). Additionally, some important (political) measures have been taken to improve the condition in woodindustry sector (see Kropivšek et al., 2017).

For both wood industry sub-sectors C16 (wood processing-except furniture) and C31 (manufacture of furniture), improvements have been observed in the last few years. We analyzed 40 financial indicators, of which 15 were examined in more detail, and found a noticeable deterioration in the years following the economic crisis (2008-2010), something that is especially true for sub-sector C31. However, since 2013 the values of most indicators for both sectors have improved. With DEA analysis measuring the relative efficiency of production units (in our case sectors), the results showed that in general the efficiency of sub-sector C16 is higher than in C31. Some models, as confirmed by DEA analysis, show a relative deterioration in efficien- cy for the years 2007-2010, but in most cases improvements have occurred in recent years. With these findings, it has been proven that the efficiency of both sub-sectors is increasing, which is a necessary condition for their long-term development. Sub-sector C31 shows the worst performance in profitability ratios and the best in efficiency ratios. However, a remarkable improvement in the efficiency of these ratios has been seen in recent years, which is also true for the activity ratios. For all models, the performance of sub-sector $\mathrm{C} 16$ is better than that of $\mathrm{C} 31$. The results of t-test prove that the difference between these two sub-sectors is statistically significant, as the differences of more than half of financial indicators between them are statistically significant.

Since the sector consists of individual companies, its effectiveness depends on the efficiency of each particular company within the sector. It is necessary to ensure effective operations at the company's level based on the appropriate (business) decisions of their managers. The results of the current study indicate that much needs to be done in the field of profitability and value added, as weaknesses in these areas have caused low(er) efficiency of the activity ratios. On the other hand, managerial decisions often depend on sectoral economic policies, whose creators need to have as much information as possible in order to create more favorable conditions for the business environment. As such, the in-depth financial analysis presented in this work also has high practical value.

This work has the following limitations. First, it only compared two sub-sectors, and thus there were only two DMUs in the DEA models. Moreover, despite the use of DEA window analysis, which increased the sample size, it still remained small, as can be seen in the relatively large number of results with an efficiency equal to 1 . In the future, we intend to broaden our analysis by examining other European countries, which will increase the number of DMUs and also enable us to compare Slovenian achievements to those seen in other countries. 


\section{Acknowledgements - Zahvala}

The authors acknowledge the financial support from the Slovenian Research Agency (research core funding No. P4-0015 and P4-0059).

\section{REFERENCES}

\section{LITERATURA}

1. Asmild, M.; Paradi, J. C.; Aggarwall, V.; Schaffnit, C., 2004: Combining DEA window analysis with the Malmquist index approach in a study of the Canadian banking industry. Journal of Productivity Analysis, 21 (1): 67-89.

2. Berger, A. N.; Humphrey, D. B., 1997: Efficiency of financial institutions: international survey and directions for future research. European Journal of Operational Research, 98 (2): 175-212.

3. Braunsberger, F.; Hlavaty, M.; Schlamberger, N.; Stevanovič, S., 2010: Standardna klasifikacija dejavnosti 2008. Ljubljana, Statistični urad Republike.

4. Brigham, E.; Huston, J. F., 2009: Fundamentals on financial management. Mason, Ohio, South-Western/Thomson Learning.

5. Cooper, W. W.; Seiford, L. M.; Tone, K., 2007: Data Envelopment Analysis: A Comprehensive Text with Models, Applications, References and DEA-Solver Software. $2^{\text {nd }}$ ed. New York, Springer Science+Business Media.

6. Delen, D.; Kuzey, C.; Uyar, A., 2013: Measuring firm performance using financial ratios: A decision tree approach. Expert Systems with Applications, 40 (10): 3970-3983. https://doi.org/10.1016/j.eswa.2013.01.012.

7. Elliot, B.; Elliot, J., 1996: Financial accounting \& reporting. $2^{\text {nd }}$ ed. London: Prentice Hall International UK Limited.

8. Fabozzi, F. J.; Peterson, P. P., 2003: Financial management and analysis. $2^{\text {nd }}$ ed. Hoboken, New Jersey, John Wiley \& Sons Inc.

9. Fenyves, V.; Tarnóczi, T.; Zsidó, K., 2015: Financial Performance Evaluation of Agricultural Enterprises with DEA Method. Procedia Economics and Finance, 32: 423431. https://doi.org/10.1016/s2212-5671(15)01413-6.

10. Friedlob, G. T.; Schleifer, L. F., 2003: Essentials of financial analysis. New Jersey, John Wiley \& Sons, Inc.

11. Gitman, L. J., 2004: Principles of managerial finance. $10^{\text {th }}$ ed. Pearson Education.

12. Gombola, M. J.; Ketz J. E., 1983: Financial Ratio Patterns in Retail and Manufacturing Organizations. Financ. Manage, 12 (2): 45-56.

13. Halkos, G. E.; Tzeremes N. G., 2012a: Industry performance evaluation with the use of financial ratios: An application of bootstrapped DEA. Expert Systems with Applications, 39 (5): 5872-5880. https://doi.org/10.1016/j.eswa.2011.11.080.

14. Halkos, G. E.; Tzeremes, N. G., 2012b: Analyzing the Greek renewable energy sector: A Data Envelopment Analysis approach. Renewable and Sustainable Energy Reviews, 16 (5): 2884-2893. https://doi.org/10.1016/j.rser.2012.02.003.

15. Helfert, E. A., 2001: Financial analysis tools and techniques: a Guide for Managers. New York, McGraw-Hill.

16. Higgins, R. C., 1995: Analysis for financial management. Chicago, Irwin.

17. Hoang Bui, Y.; Sarath, D.; Ahmed, A. D., 2016: Efficiency of Australian superannuation funds: a comparative assessment. Journal of Economic Studies, 43 (6): 10221038. https://doi.org/10.1108/JES-05-2015-0088.
18. Hollingsworth, B.; Smith, P., 2003: Use of ratios in data envelopment analysis. Applied Economics Letters, 10 (11): 733-735. https://doi.org/10.1080/1350485032000133381.

19. Hornby, W.; Gammie, B.; Wall, S., 1997: Business economics. London, Addison Wesley Longman Ltd. https://doi.org/10.1016/S2212-5671(15)01413-6

20. Kropivšek, J.; Jošt, M., 2013: Financial analysis of a sector: a case of Slovenia wood industry. In: Jelačić, D. (ed.), Markets for wood and wooden products. Zagreb, WoodEMA, i.a., 57-76.

21. Kropivšek, J.; Grošelj, P.; Likar, B.; Jošt, M., 2011: Economics of Slovenian wood-industry. In: Development trends in economics and management in wood processing and furniture manufacturing: proceedings. Kozina, Slovenia: International Scientific Conference: 91-96.

22. Kropivšek, J.; Milavec, I.; Likar, B., 2017: Analiza poslovanja slovenske lesne panoge / Slovenian wood industry sector analysis. Les/Wood, 66 (2): 47-56. https://doi.org/10.26614/les-wood.2017.v66n02a05.

23. Li, H.; Wu, L., 2016: Analysis of financial support efficiency for China's wind power industry. Energy Sources, Part B: Economics, Planning, and Policy, 11 (11): 10351041. https://doi.org/10.1080/15567249.2016.1185480.

24. Likar, B.; Valentinčič, E., 2017: Informacija o poslovanju lesne in pohištvene industrije $\mathrm{v}$ letu 2016. Ljubljana: GZS (Information on the operations of the wood industry in the year 2016).

25. Mramor, D., 2002: Teorija poslovnih financ. Ljubljana, Ekonomska fakulteta.

26. Nikoomaram, H.; Mohammadi, M.; Mahmoodi, M., 2010: Efficiency measurement of enterprises using the financial variables of performance assessment and data envelopment analysis. Applied Mathematical Sciences, 4 (37): 1843-1854.

27. Oberholzer, M.; van der Westhuizen, G., 2004: An empirical study on measuring efficiency and profitability of bank regions. Meditari Accountancy Research, 12 (1): 165-178.

28. Palepu, K. G.; Healy, P. M.; Bernard, V. L., 2004: Business analysis \& valuation: Using Financial Statements. $3^{\text {rd }}$ ed. Ohio, Mason.

29. Pastor, J. T.; Ruiz, J. L., 2007: Variables with negative values in Dea. In: Zhu, J.; Cook, W. D. (eds.), Modeling Data Irregularities and Structural Complexities in Data Envelopment Analysis, pp. 63-84. Boston, MA, Springer US.

30. Peršak, C., 2011: Vedno je pravi čas za analizo. Podjetnik, 5: 26-29.

31. Peterson Drake, P.; Fabozzi, F. J., 2010: The Basics of Finance: An Introduction to Financial Markets, Business Finance, and Portfolio Management. John Wiley \& Sons.

32. Peterson, P. P.; Fabozzi, F. J., 1999: Analysis of financial statements. Hoboken, New Jersey, John Wiley \& Sons, Inc.

33. Pirc Barčić, A.; Liker, B.; Motik, D.; Moro, M., 2017: Financial analysis of Croatian furniture Industry. In: Grbac, I. (ed.), Implementation of wood science in woodworking sector - procedings. Zagreb, University of Zagreb, Faculty of Forestry.

34. Pratt, J., 1990: Financial accounting. Glenview: Scott, Foresman/Little, Brown Higher Education.

35. Rebernik, M., 2008: Ekonomika podjetja. Ljubljana, Gospodarski vestnik.

36. Rees, B., 1995: Financial analysis. $2^{\text {nd }}$ ed. London, Prentice Hall.

37. Samuelson, P. A.; Nordhaus, W. D., 2002: Ekonomija. GV založba, Ljubljana; Mate, Posušje. 
38. Sayari, N.; Simga Mugan, C., 2016: Industry specific financial distress modeling. BRQ, 20 (1). https://doi.org/10.1016/j.brq.2016.03.003.

39. Seiford, L. M.; Zhu, J., 2002: Modeling undesirable factors in efficiency evaluation. European Journal of Operational Research, 142 (1): 16-20.

40. Slapničar, S., 2004: Analiza računovodskih izkazov. Ljubljana, Ekonomska fakulteta.

41. Tekavčič, M., 2002: Merjenje in presojanje uspešnosti poslovanja. In: Možina, S. (ed.), Management. Radovljica, Didakta, 664-692.

42. Tratnik, M.; Zager, M.; Zupanec, J., 2001: Key factors of (non)competitiveness of Slovene wood industry. In: Ways for improving woodworking industry for transitional economics: proceedings. Preddvor, Slovenia: International Symposium, 107-114.

43. Vance, D. I., 2003: Financial analysis and decision making: Tools and Techniques to Solve Financial Problems and Make Effective Business Decisions. New York, McGraw-Hill.

44. ${ }^{* * *}$ Bisnode, 2018. Available at: https://bonitete.bisnode. si_(Accessed Feb. 7, 2018).

45. *** Analitika GZS, 2018. Available at: https://analitika. gzs.si/ (Accessed Jan. 25, 2018).

46. ${ }^{* * *}$ Ajpes FI=PO, 2018: Financial Data - Explanation for companies. [online] Available at: https://www.ajpes. si/fipo/Pojasnila_za_gd.asp?language=english (Accessed Jan. 15, 2018).
47. *** NACE, 2018: Glossary: Statistical classification of economic activities in the European Community. Available at: http://ec.europa.eu/eurostat/statistics-explained/ index.php/Glossary:Statistical_classification_of_economic_activities_in_the_European_Community_ (NACE) (Accessed Jan. 15, 2018).

48. *** Ajpes JOLP, 2017: Public posting of annual reports. Available at: https://www.ajpes.si/jolp/ (Accessed Dec. $15,2017)$

49. *** UMAR, 2017: Development report 2017. Ljubljana: IMAD. Available at: http:/www.umar.gov.si/en/slovenias-development/report/news/porocilo-o-razvoju$2017 /$ tx_news_pi $1 \% 5 \mathrm{Bcontroller} \% 5 \mathrm{D}=\mathrm{News} \& \mathrm{tx}$ news pi $1 \% 5$ Baction $\% 5 \mathrm{D}=$ detail $\&$ cHash $=84 \mathrm{f} 098 \mathrm{a} 88 \mathrm{dbf}$ d9edae6ca6c7da518755 (Accessed Feb. 20, 2018).

50. *** ZGD-1-UPB3, 2009: Zakon o gospodarskih družbah. Available at: https://www.uradni-list.si/1/objava. jsp?sop=2009-01-3036 (Accessed Feb. 7, 2018).

\section{Corresponding address:}

Asist. Prof. Jože KROPIVŠEK, Ph.D.

University of Ljubljana, Biotechnical Faculty Department of Wood science and Technology Ljubljana, SLOVENIA e-mail: joze.kropivsek@bf.uni-lj.si 